\title{
Physiological Response of Fenugreek (Trigonella foenum-graecum L.) plant Treated by Farmyard Manure and Two Selected Seaweeds as Biofertilizers.
}

\author{
M.G.Battah ${ }^{1}$, M.A.Mostfa ${ }^{1}$, H.M.Eladel ${ }^{1}$, A.S.Soror ${ }^{2}$ and M.M.Tantawy ${ }^{1}$ \\ ${ }^{1}$ Botany and Microbiology, Dept., Faculty of Science, Benha Univ., Benha, Egypt. \\ ${ }^{2}$ Botany and Microbiology, Dept., Faculty of Science, Zagazig Univ., Zagazig, Egypt.
}

\section{Abstract}

E-Mail: Mai_tantawy92@yahoo.com

A pot experiment was conducted to test the effect of two selected seaweeds belonging to different taxonomic group's Chlorophyceae (Ulva lactuca) and Rhodophyceae (Jania rubens) as well as farmyard manure (FYM) on growth and biochemical parameters of Trigonella foenum-graecum (fenugreek). Physico- chemical analysis of FYM and biochemical characterization of the two selected algae including (elemental analysis, hormones and pigments) were measured. Also, growth parameters of fenugreek as shoot and root length, total plant height, leaf area, fresh weight and biochemical parameters including carbohydrates fractions (direct, total reducing value, polysaccharides), nitrogen fractions (in soluble protein, total soluble nitrogen and total nitrogen), chlorophyll contents ( $\mathrm{Ch} \mathrm{a,b}$ ) and carotenoid in addition to fatty acids were estimated. The obtained results clarified that Jania rubens has a pronounced stimulatory effects on test plant if compared with Ulva lactuca and FYM respectively. Since, the alga has a high amount of macro, micro elements as well as phytohormones indole acetic acid (IAA, $110 \mathrm{ug} / \mathrm{g}$ ), Kinetin (Kin, 68ug/g), naphthalene acetic acid (NAA $50 \mathrm{ug} / \mathrm{g}$ ) and gibberellins (GA3, $11 \mathrm{ug} / \mathrm{g}$ ). The alga increased growth parameters (root length, $8.8 \mathrm{~cm}$, shoot length $9 \mathrm{~cm}$, leaf area 1.6 $\mathrm{cm}$ and fresh weight was $0.40 \mathrm{~g}$ ). The alga enhanced pigment fractions with special reference $\mathrm{Ch}$ (b) since it was 1.15 $\mathrm{mg} / \mathrm{g}$ more than its irrespective values in Ulva and FYM. As well as insoluble protein was $19.09 \mathrm{mg} / \mathrm{g}$, total soluble nitrogen was $39.71 \mathrm{mg} / \mathrm{g}$ and total nitrogen was $180 \mathrm{mg} / \mathrm{g}$. Also, the alga has a promotive effect on total carbohydrates since it was $82.84(\mathrm{mg} / \mathrm{g})$. Moreover, the different treatments led to a reduction in saturated fatty acids (SFA) and increase the unsaturated fatty acids (USFA) if compared with control. The fatty acids profile was due to the reduction of $\mathrm{C}_{18: 0}$, $\mathrm{C}_{20: 0}$ and increase in $\mathrm{C}_{18: 1}, \mathrm{C}_{18: 2}$ and $\mathrm{C}_{18: 3}$. The objective of this study is to evaluate the effect of two selected marine algae Ulva lactuca (Chlorophyta) \& Jania rubens (Rhodophyta) as well as FYM on some phenological and biochemical parameters of Trigonella foenum-graecum .

\section{Keywords: Chlorophyta, Rhodophyta, phytohormones, Trigonella foenum-graecum L., Biofertilizers.}

\section{Introduction}

As a result of industrialization and a rapid development in technology as well as fast growth rate of population, this led to restrict the cultivated land and food production. To meet out this increasing demand, farmers used different inorganic fertilizers to increase the crop productivity, this led to damage the soil ecosystem extensively. Such treatment makes the soil environment unsuitable for further cultivation in the future [1]. As well as chemical fertilizers are harmful to human either directly or indirectly, since the toxic chemicals (arsenic and cadmium) from chemical fertilizers accumulate in plant products causing health problem in human by bio magnification [2].Also, the cost of chemical fertilizers is very high and sometimes not available. Many trials are done to discover the suitable bio fertilizers for replacing the chemical ones [3].

Fenugreek (Trigonella foenum-graecum L.) belonging to the family Leguminosae and Sub family Papilionacea. It is widely used as spice and condiment [4], as well as medicinal plant since both seeds \& leaves are a rich source of a wide diversity of medicinally phytochemicals [5].The antioxidant activity of Fenugreek was found to prevent oxidative damage caused by reactive oxygen species (ROS) by acting as ROS scavengers and may also prevent the occurrence of diseases such as cancer and aging [6 ]. Moreover, continuous feeding of $1 \%$ fenugreek seed powder (FSP) prevent colon cancer, inhibit growth of breast, pancreatic and prostate cancer cell lines (PCa) [7]. Regarding organic fertilizers, [1] postulated that FYM has a positive response to yield attributes and yield. This might be due to the availability of sufficient amount of plant nutrients resulting in better uptake. [8] showed that FYM improve soil physical properties and act as a source of energy for soil micro flora which make the transformation unavailable form of nutrients present in soil and applied as fertilizer into available form which is readily utilized by growing plants [9]. Also, it increases the protein content, this may be due to the availability of all the essential nutrients which are present in organic matter and their continuous mineralization [10] as well as it increases organic carbon content of soil and increase the biological activities of microbes in soil [11]. Finally, the organic manure is easily available to the farmers and its cost is effective. Seaweeds are marine macro algae, related to plant Kingdom thallophyta [12]. The direct benefit of seaweeds is their use as food, feed and fertilizers, since they are the only source of phytochemical production as agar, alginate, contain more than 60 trace elements, protein, iodine, bromine, vitamins [13]. [14] Stated that marine macro algae are ecofriendly environmental tools in farming. Since they produce commercial specific compounds including microcides, insecticides, nematocides, biofertlizers and soil conditioners, as well as they contain bioactive compounds like fatty acids especially polyunsaturated fatty acids (PUFAs), proteins, sulfated polysaccharides, carotenoids and polyphenols are 
considered to have bactericidal, antiviral and fungicidal effects. These bio control agents are useful indicators for improving cultivation practices in diverse habitats. Moreover, [15] stated that using of seaweed as fertilizers are preferable not only due to their nitrogen, phosphorus and potash content but also due to the presence of trace elements and metabolite similar to plant growth regulators. They contain many growth promoting hormones like auxin, gibberellin, and cytokinin, trace elements, organic substances like vitamins, amino acids, micro and macro nutrients. Moreover, [16] claimed that soaking of Vigna sinensis with aqueous extract of Sargassum wightii and Caulerpa chemnitzia, promoted the seedling growth including the parameters of shoot length, root length, fresh weight and dry weight when compared to the water soaked controls. Parallel, [17] stated that seaweed fertilizers stimulate metabolism by increasing chlorophyll production, carotenoids, protein content in shoot \& root as well as amino acid, reducing sugar, total sugar in shoot. [18] reported that algal hormones (IAA, GA3, and cytokinins) stimulate plant growth directly or indirectly by interacting with soil microbes for bio mineralization or plant-microbe symbiosis, thereby in-creasing nutrient availability.

\section{Material and methods}

\subsection{Algal collection and selection of test plant}

Red alga (Jania rubens) and green alga (Ulva lactuca) used in the present investigation were collected from Alexandria beaches. Collected seaweeds were washed with sea water to remove unwanted impurities and other debris. Then thoroughly washed with tap water for 3 times to remove all the epiphytes, sand particles and other fauna. After shade drying, it was cut into small pieces and kept in hot air oven for one day at 40 oC. Grind dried seaweeds by using ceramic mortar .

Mix well the dried powder with pre-prepared sterilized soil in a pot containing $12 \mathrm{~g}$ powder $/ 250 \mathrm{~g}$ clay soil per pot. Three replicates for each treatment, in addition to FYM (12 g /250 g clay soil). Twenty seeds of Trigonella foenum-graecum in a pot were sowed in soils, the experiment was lasted for one month and irrigated as needed.

The seeds of the used plant, in present study were procured from seed storage bank of Agriculture ministry. Viable and healthy seeds free from visible infection, with uniform size were segregated.
They were traded with 5\% sodium hypochlorite for 8 minutes, and then rinsed with distilled water several times before sowed in soil.

\subsection{Growth Parameters}

Growth parameters viz., root, shoot length, total plant height, leaf area, and, fresh weight of whole plant was measured as suggested by [19].

\section{Biochemical Activities}

\subsection{Estimation of Chlorophyll Contents}

Chlorophyll content of both two selected algal seaweeds and the test plant were estimated as method described by [20].

\subsection{Estimation of Nitrogen Contents}

Total nitrogen was estimated according to [21], Total soluble nitrogen was ascertained according to [22], protein estimated by [23].

\subsection{Estimation of Carbohydrate Contents}

Carbohydrates extraction was carried out according to [24], direct reducing value was determined by [25] as modified by [26], polysaccharides by [27].

\subsection{Estimation of Phytohormones}

Phytohormones were estimated according to [28].

\subsection{Extraction and determination hormones}

Weigh 50mg from sample, add $100 \%$ cold $\mathrm{MeOH}$ and homogenize for $5 \mathrm{~min}$ at $4 \mathrm{c}$. Soaking for $24 \mathrm{~h}$, filter and grind it with 5 times $80 \%$ cold $\mathrm{MeOH}$, filter again and residue grind it with 5 times $80 \%$ cold $\mathrm{MeOH}$, filtrate and add $50 \mathrm{ml}$ petroleum ether Evaporate to enrich. Enriched elute is acidified with $0.1 \mathrm{~mol} / \mathrm{L}$ to $\mathrm{pH}$ 2.8-3.0 then dissolve in $8 \mathrm{ml} 100 \%$ redistilled $\mathrm{MeOH}$. Filtered through $0.45 \mu \mathrm{m}$ MF Millipore filters and injected into HPLC .

\subsection{HPLC Conditions}

The detector wavelength was set at $260 \mathrm{~nm}$. A reversed-phase C18 column $(15 \mathrm{~cm} \times 4.6 \mathrm{~mm}, 5 \mu \mathrm{m}$, Discovery, USA) was used for separation. The mobile phase was a mixture of methanol and $\mathrm{KH} 2 \mathrm{PO} 4 \quad(25$ $\mathrm{mM}, \mathrm{pH} 3$ ), eluting under gradient conditions as detailed in following Table(1) the flow rate was $1.0 \mathrm{~mL}$ min1.Mobile phase elution profile for the SPME-HPLC analysis of phytohormones.

Table (1) Mobile phase elution profile for the SPME-HPLC analysis of phytohormones.

\begin{tabular}{|c|c|c|c|}
\hline Time (min) & Percentage of Methanol (\%) & Time (min) & Percentage of Methanol (\%) \\
\hline 0 & 10 & 23 & 55 \\
\hline 4 & 10 & 25 & 10 \\
\hline 8 & 30 & 30 & 10 \\
\hline $\mathbf{0}$ & 10 & 23 & 55 \\
\hline
\end{tabular}

\subsection{Apparatus}

Hewlett Packard HPLC system (Agilent, USA) constructed of a quaternary.

HP 1260 pump and HP 1260 series multiple wave length detector. 


\subsection{Estimation of Fatty Acids contents}

Fatty acids estimated by using HPLC as method described by [29].

\subsection{Physico-Chemical analysis of Soil and Farmyard manure}

Preparation of soil water extract and farmyard manure, both soil and farmyard manure samples were extracted with distilled water (1:5 w/v) according to [30].

\subsection{Elemental estimation}

The concentration of elements in the samples either soil extract, FYM were estimated by using atomic absorption according to [31].

\subsection{Estimation of phosphorus}

The concentration of phosphorus element was estimated by as method described by [32].

Estimation of \% of oxidizable carbon, total organic carbon and organic matter was done according to [33].

\section{Results and Discussion \\ 4.1 Characterization of clay soil extracts and farm yard manure}

Regarding physicochemical characters of soil extract and FYM, Data in Table (2) showed that both of them are acidic at temperature $25^{\circ} \mathrm{C}$, since $\mathrm{pH}$ were $(6.6$ and 6.1) respectively. Also, FYM is rich in its mineral contents especially sodium $205.3 \mathrm{ppm}$, potassium 229.3 ppm, magnesium $16.82 \mathrm{ppm}$, iron $3.1 \mathrm{ppm}$, total phosphorus $38.5 \mathrm{ppm}$ and $\%$ total nitrogen 0.15 . Also, it was rich in percentage of total organic carbon $44 \%$ and percentage of oxidizable carbon $33 \%$ when compared with their corresponding values of soil extract. These results are in concomitant with [34], who claimed that FYM provide all major nutrients $(\mathrm{N}, \mathrm{P}, \mathrm{K}, \mathrm{Ca}, \mathrm{Mg}$, and $\mathrm{S})$ as well as microelements ( $\mathrm{Fe}, \mathrm{Mn}, \mathrm{Cu}$, and $\mathrm{Zn}$ ) to soil. Also, they found that both soil total nitrogen and available phosphorus were increased following FYM application. This was due to direct addition of $\mathrm{N}$ and $\mathrm{P}$ through FYM decomposition. Moreover, [35] reported that organic matter was increased following FYM application. Finally, [36] stated that FYM improves physical, chemical and biological properties of soil, since FYM is rich in natural nutrients [11].

\subsection{Characterization of the two selected seaweeds 4.3 Pigment contents}

Data present in Table (3) clarified that the pigment contents in the two tested algal species were comparable. Ulva lactuca has a high amounts of chlorophyll (a) and (b) if compared with Jania rubens, since it was $(0.183$ and $0.485 \mathrm{mg} / \mathrm{g})$ and $(0.149$ and 0.31 $\mathrm{mg} / \mathrm{g}$ ) respectively, The same observation was also recorded in carotenoids, since it was 1.393 and 0.93 $\mathrm{mg} / \mathrm{g}$, respectively. The decrease in chlorophyll (a) was compensated by the increase in chlorophyll (b).These results agree with [56] who reported that the highest total chlorophyll was recorded in the green algae and minimum in the red algae [37].

\subsection{Mineral contents}

Regarding mineral composition in the two selected algal species (Ulva lactuca) and (Jania rubens). Table (4) revealed the presence of diverse minerals either macro elements $(\mathrm{Na}, \mathrm{Fe}, \mathrm{Ca}, \mathrm{K}, \mathrm{Mg}$, and $\mathrm{P}$ ) or micro elements ( $\mathrm{Zn}, \mathrm{Mn}, \mathrm{Co}, \mathrm{Pb}, \mathrm{Cd}, \mathrm{Cu}, \mathrm{Ni}, \mathrm{Se}, \mathrm{Ag}$, and $\mathrm{Cr}$ ). It was found that Jania rubens exhibiting the higher amount of both macro and micro elements than Ulva lactuca. These results are in accordance with [38] who stated that the analysis of Jania revealed that the value of total nitrogen was maximum followed by $\mathrm{K}, \mathrm{S}, \mathrm{Mg}$, $\mathrm{Ca}$ and $\mathrm{P}$. But in the present study among the macro elements, the value of $\mathrm{K}(930.2$ and $334.4 \mathrm{ppm}), \mathrm{Mg}$ (824.6 and $404.3 \mathrm{ppm}), \mathrm{Na}(682.9$ and $174.2 \mathrm{ppm}), \mathrm{Fe}$ (68.3 and $66.59 \mathrm{ppm}$ ) in Jania and Ulva respectively whereas Ulva as green alga has high $\mathrm{Ca}$ than Jania (128.24 and $93.14 \mathrm{ppm}$ ) respectively. Also, it was found that $\mathrm{Na} / \mathrm{K}$ ratios were below 1.5 in the two selected seaweeds, 0.73 in Jaina and 0.52 in Ulva. This is very important from nutrition point of view, since, the diets with a high $\mathrm{Na} / \mathrm{K}$ ratio were related to the incidence of hypertension [39]. In parallel, the values of the estimated micro elements in Jania were higher than those of Ulva. Such results are in concomitant with [40] who claimed that the importance of seaweeds as a biofertilizer is not only from the nitrogen, phosphorus, potash, organic matter but also from elemental contents as macro and trace elements. Moreover, [41] claimed that the mineral composition in different taxonomic groups like Chlorophyceae and Rhodophyceae revealed the presence of diverse minerals such as $\mathrm{F}, \mathrm{Ca}, \mathrm{Mg}, \mathrm{Na}$, $\mathrm{K}, \mathrm{Fe}, \mathrm{Mn}, \mathrm{Zn}, \mathrm{Cu}, \mathrm{Ni}, \mathrm{Co}, \mathrm{Cr}$, and $\mathrm{Cd}$. Moreover, [42] claimed that a higher composition of minerals was found in marine seaweeds as compared to land vegetables. Consequently, variety of plants treated with seaweeds will improve their mineral nutrition and led to healthier plants to withstand better against detrimental attack by pests as well as more resistant to fungal, bacterial and insect attack [43]. Moreover, [44] explained the increase in the growth criteria might be due to the uptake of magnesium, potassium, nitrogen and iron from the seaweed extract.

\subsection{Phytohormones contents}

Analysis of phytohormones by using HPLC in the two selected seaweeds as illustrated in Table (5) which revealed that indole acetic acid (IAA), Kinetin (Kin), Naphthalene acetic acid (NAA) and Gibberellins (GA3) were higher in Jania rubens if compared with Ulva lactuca, since IAA was $(110,64.6 \mu \mathrm{g} / \mathrm{g}), \mathrm{GA} 3(11,3.7$ $\mu \mathrm{g} / \mathrm{g})$, Kin $(68,37 \mu \mathrm{g} / \mathrm{g})$ and NAA $(50,19 \mu \mathrm{g} / \mathrm{g})$ for Jania and Ulva, respectively. The study results may confirm that Jania rubens has a biological effect followed by Ulva lactuca, as it contains high amount of phytohormones. These results are in accordance with [45] stated that the stimulatory effect of red algae on plant growth was due to the presence of high quantities of phytohormones. Also, [46] pointed out the presence of some plant growth regulators in algal-based bio fertilizers, like auxins, gibberellin, and cytokinins. [47] 
confirmed that one of the promising applications of seaweeds is their use as plant bio-stimulants. This impact is explained on the basis of them contains bioactive substances such as cytokinins, auxins gibberellins, abscicic acid, ethylene polyamines betaines in algal extract.

Regarding growth parameters as root length, shoot length, leaf area and fresh weight, Table (6) clarified that the seeds treated with either FYM or Ulva lactuca or Jania rubens showed better results in all tested growth parameters if compared to control. The most stimulatory effect was recorded in Jania rubens, followed by Ulva lactuca and FYM since it was 8.80, 7.3 and $6.5 \mathrm{~cm}$ in root length $9.00,9.3$ and $8.7 \mathrm{~cm}$ shoot length, 1.6, and 1.56, $0.99 \mathrm{~cm} 2$ in leaf area, fresh weight was $0.22,0.25$ and $0.12 \mathrm{~g}$ in Jania, Ulva and FYM respectively. Our results are in correlation with [48] who stated that seaweed biofertilizers are found to be superior to FYM and chemical fertilizer because of the presence of high amount of organic matter, which helps in moisture retaining capacity and minerals nutrients available to plants [49] demonstrated that the usage of seaweeds as biofertilizers increased the growth parameters as well as fresh and dry weight of roots and shoots [50]. Such stimulatory effects could be explained according to [51], since algae can retain nutrients and release them slowly to the plants, as well as they contain important nutrients as, phosphorus (20.9 \& $2.095 \mathrm{ppm})$, potassium (930.2 \& $334.4 \mathrm{ppm}$ ), Magnesium (824.6 $\& 404.3 \mathrm{ppm})$, Sodium (682.9 \&174.2 ppm ), Iron (68.3 \& $66.59 \mathrm{ppm})$. Zinc $(0.5031 \& 0.3895 \mathrm{ppm})$, Manganese (0.3514 \& $0.2873 \mathrm{ppm})$, Cupper $(0.4835$, $0.1553 \mathrm{ppm}$ ) in Jania and Ulva respectively, (Table 4). Moreover, the two selected seaweeds were rich in phytohormones, since they contain $(11,3.7 \mu \mathrm{g} / \mathrm{g}$ GA3), $(110,64.6 \mu \mathrm{g} / \mathrm{g}$ IAA, ( $50 \& 19 \mu \mathrm{g} / \mathrm{g}$ NAA) and $(68,37$ $\mu \mathrm{g} / \mathrm{g}$ Kin )in Jania and Ulva respectively. These results are in agreement with [52] postulated that the enrich soil with hormones as gibberellins which stimulate seed germination, since it induces hydrolytic enzymes in the aleuronic layer surrounding endosperm [53]. This means that Gibberellic acid act as a signal in the seed germination by activating amylase genes in aleuronic layer. Parallel, the presence of cytokinin with magnesium enhance the growth due to cytokinin is essential promoting hormone and magnesium is the chief constituent in chlorophyll biosynthesis [54]Also auxin which are important for rooting in plants [55]. They contain in addition, precursors of compounds elicitors that promote germination, growth and maintenance of plant health [49].

In case of pigment, Table (6) clarified that Trigonella foenum-graecum seeds treated with different treatments (FYM and biofertilizers Ulva or Jania) showed better response in pigment fraction, with special reference chlorophyll (b). The previous results showed that chlorophyll (b) was increased since, it was (1.15, 0.875 , and $0.84 \mathrm{mg} / \mathrm{g}$ in Jania, Ulva and FYM respectively, if compared with control $(0.36 \mathrm{mg} / \mathrm{g})$. The increase in chlorophyll (b) was associated by the decrease in chlorophyll (a). Our results coincide with [56] who reported that the highest total chlorophyll was recorded in the green algae and minimum in the red algae. $[37,49]$ observed that usage of seaweed extracts as a biofertilizer increased the pigment content chlorophyll (a,b). Continually, [57] explained the increase in chlorophyll content $(\mathrm{a}, \mathrm{b})$ and total chlorophyll was due to reduction in chlorophyll degradation which may be caused in part by betaines, also may be due to the seaweeds extracts were rich of glycine betaine. This component delays the loss of photosynthetic activity by inhibiting chlorophyll degradation during storage conditions in isolated chloroplasts [58], increase in number and size of the chloroplast and better grana development [59]. Finally, [60] concluded that the seaweed fertilizer of Jania rubens when applied to seed plant showed better results in pigment concentration if compared with Ulva lactuca. This may be due to presence of magnesium and iron which influenced the chlorophyll synthesis, this was confirmed by our chemical analysis of seaweed extracts since $\mathrm{Mg}$ was 824.6 and $404.3 \mathrm{ppm}$ and Fe was 68.3 and 66.59 in Ulva lactuca and Jania rubens, respectively.

With respect to changes in carbohydrate contents of Trigonella foenum-graecum plant treated with FYM and Ulva lactuca and Jania rubens. Table (7) generally showed an enhancement effect on total carbohydrates in all treatments if compared with their irrespective control. The highest value of total carbohydrates was recorded in Jania. Since it was $(82.84 \mathrm{mg} / \mathrm{g})$, followed by FYM $(82.29 \mathrm{mg} / \mathrm{g})$ and Ulva $(79.30 \mathrm{mg} / \mathrm{g})$. The increase in total carbohydrates was accompanied with a reduction in polysaccharides $(24.65,24.42,24.03 \mathrm{mg} / \mathrm{g}$ ) and a marked increase in total reducing sugar (58.19, $58.35,54.88 \mathrm{mg} / \mathrm{g}$ ), especially sucrose accumulation $(35.19,33.38,31.10 \mathrm{mg} / \mathrm{g})$. In Jania, FYM and Ulva respectively.

The possible reason for sucrose accumulation may be due to converting the carbon skeleton of nitrogenous compounds to carbohydrates ones as well as considerable degradation of polysaccharide [61]. Moreover, the high content of carbohydrate in red algae is might be due to higher phycocolloid content in their cell walls [62]. Also, [63]stated that the sucrose formation seemed to be accelerated by GA3, by stimulating starch degradation and diverting the intermediate compounds such as triose phosphate away starch storage to build up sucrose. Moreover, the two tested seaweeds are rich in $\mathrm{Mg}++, \mathrm{Ca}++$ and $\mathrm{Mn}++$ which play an important role in photosynthesis and carbohydrates metabolism. Since $\mathrm{Mg}++$ is a constituent of chlorophyll molecule and also many enzymes involved in carbohydrates metabolism requires $\mathrm{Mg++}$ as activator for many enzymes as glucokinase, fructokinase, Hexokinase, phosphopentokinase and carboxylase, Moreover, manganese markedly stimulate hill reaction [64]. Moreover, [65,66] indicated that using seaweed as fertilizer at low concentration enhances total carbohydrate, [67] as well as total soluble sugars $[68,69]$. 
Regarding total nitrogen Table (8) showed that the different treatments had a stimulatory effect on the content of total nitrogen of test plant.

The pronounced stimulatory effect of total nitrogen was recorded in plant treated with Jania rubens since it was $(180 \mathrm{mg} / \mathrm{g})$, followed by Ulva lactuca $(156 \mathrm{mg} / \mathrm{g})$ and FYM $(71.6 \mathrm{mg} / \mathrm{g})$ respectively.

Such stimulatory effect may be due to the different treatments have a promotive effect on total soluble nitrogen, since it was $39.71,31.27$ and $11.38 \mathrm{mg} / \mathrm{g}$ as well as protein was $19.09,19.01$ and $18.73 \mathrm{mg} / \mathrm{g}$ in Jania, Ulva and FYM, respectively Table (8).

The previous results are in accordance with [70] reported that treatment of fenugreek plant with Sargassum SLF resulted in increasing in total nitrogen activity if compared with Hoagland treated fenugreek plant. [71] Who stated that crude extract of 3 green seaweeds and three red algae increased protein content in both root and shoot system. [50; 69 and 66]found that the seaweed Ascophyllum nodosum stimulate protein content in Phaseolus vulgaris as shown in Vicia faba, soluble protein and amino acids content [72].

Finally, [70] claimed that increased the protein content, was due to enhanced the absorption of most necessary elements by seedling as well as associated with increased nitrate reeducates activity in the treated plants, or attributed to the growth hormones produced by bio stimulant [73].
The fatty acid profiles of Trigonella foenumgraecum seedling pretreated with organic fertilizer (FYM) and the two selected biofertilizers Ulva lactuca and Jania rubens exhibited a different value.

Table (9) showed that the major saturated fatty acid was palmitic (C16:0) for FYM, Ulva lactuca and Jania rubens respectively.

Regarding monounsaturated fatty acid profiles, the same trend was also observed. In case of poly unsaturated fatty acids profiles, it is similar to MUFA. The previous results were confirmed by unsat/sat index.

Finally, we can deduce that the different treatment led to a reduction in (SFA) and increase in unsaturated fatty acids.

The profile was due to the reduction of C18:0, C20:0 and increase in C18:1, C18:2 and C18:3. These results are in agreement with [74] who stated that lipids are the main source of calories and essential fatty acids are needed for men and animals.

Plant synthesizes a huge variety of fatty acids although a few are major and common constituents like palmitic, oleic, linoleic acid and linolenic acid. Also, lipids are necessary for the biogenesis of cell membrane as well as acting as signal molecules. [75] Stated that algal respond to unsuitable condition by consuming ATP to convert the saturated fatty acids to un saturated ones. [76] claimed that application of biofertilizer led to decrease saturated fatty acids, plamatic and stearic while increased the main unsaturated fatty acid oleic, Linoleic and linolenic thus the yield oil become safer for human consumption.

Table (2) Physico-chemical analysis of soil water extract and farmyard manure.

\begin{tabular}{llcc}
\hline & & Soil extract & Farm yard manure (FYM) \\
\hline \multirow{2}{*}{ Physical characters } & pH & 6.50 & 6.10 \\
& Temperature $\left({ }^{\circ} \mathbf{C}\right)$ & 25 & 25 \\
& Sodium (ppm) & 53.26 & 205.30 \\
& Calcium (ppm) & 23.97 & 3.99 \\
& Potassium (ppm) & 10.10 & 229.30 \\
& Magnesium (ppm) & 13.10 & 16.82 \\
& Iron (ppm) & 0.10 & 3.10 \\
& Total Phosphorus (mg/g) & 1.40 & 38.50 \\
& Total Nitrogen (\%) & 0.10 & 0.15 \\
& \% of oxidizable carbon & $30.75 \pm 2.25$ & $33 \pm 4.50$ \\
& \% of total organic carbon & $41 \pm 3.00$ & $44 \pm 6.003$ \\
& \% of organic matter & $70.72 \pm 5.17$ & $75.89 \pm 10.35$ \\
\hline
\end{tabular}

Table (3) Pigments contents expressed as $(\mathrm{mg} / \mathrm{g})$ in two selected marine algae Ulva lactuca and Jania rubens.

\begin{tabular}{lcccc}
\hline Algae & Ch $(\mathbf{a})$ & $\mathbf{C h}(\mathbf{b})$ & Total $(\mathbf{a}+\mathbf{b})$ & Carotenoid \\
\hline Ulva lactuca & $0.183 \pm 0.02$ & $0.485 \pm 0.03$ & 0.668 & $1.393 \pm 0.05$ \\
Jania rubens & $0.149 \pm 0.03$ & $0.31 \pm 0.02$ & 0.459 & $0.93 \pm 0.005$ \\
\hline
\end{tabular}


Table (4) Elemental composition (ppm) in two selected marine algae Ulva lactuca and Jania rubens.

\begin{tabular}{lcc}
\hline Element & Jania rubens & Ulva lactuca \\
\hline $\mathbf{N a}$ & 682.90 & 174.20 \\
$\mathbf{F e}$ & 68.30 & 66.59 \\
$\mathbf{C a}$ & 93.14 & 128.24 \\
$\mathbf{K}$ & 930.20 & 334.40 \\
$\mathbf{M g}$ & 824.60 & 404.30 \\
$\mathbf{P}$ & 20.90 & 2.095 \\
$\mathbf{Z n}$ & 0.5031 & 0.3895 \\
$\mathbf{M n}$ & 0.3514 & 0.2873 \\
$\mathbf{C o}$ & 0.0348 & 0.0004 \\
$\mathbf{P b}$ & 0.4347 & 0.1428 \\
$\mathbf{C d}$ & 0.0194 & 0.0108 \\
$\mathbf{C u}$ & 0.4835 & 0.1553 \\
$\mathbf{N i}$ & 0.1138 & 0.0312 \\
$\mathbf{S e}$ & 0.632 & 0.2541 \\
$\mathbf{A g}$ & 1.2651 & 0.5178 \\
$\mathbf{C r}$ & 0.2739 & 0.196 \\
\hline
\end{tabular}

Table (5) HPLC analysis of phytohormones (ug/g) dry weight of the two selected seaweeds Jania rubens and Ulva lactuca.

\begin{tabular}{lcccc}
\hline Seaweeds & IAA & Kin & NAA & GA3 \\
\hline Jania rubens & 110 & 68 & 50 & 11 \\
Ulva lactuca & 64.60 & 37 & 19 & 3.70 \\
\hline & & & Kin= Kinetin. \\
\multicolumn{2}{l}{ IAA= Indole acetic acid. } & & & GA3= Gibberellins.
\end{tabular}

Table (6) Effect of different treatments FYM, Ulva lactuca and Jania rubens applications on growth parameters and pigment contents of Trigonella foenum-graecum L. after 30 days.

\begin{tabular}{lcccccccc}
\hline Treatment & $\begin{array}{c}\text { Root length } \\
(\mathbf{c m})\end{array}$ & $\begin{array}{c}\text { Shoot length } \\
(\mathbf{c m})\end{array}$ & $\begin{array}{c}\text { Leaf area } \\
\left(\mathbf{c m}^{\mathbf{2}}\right)\end{array}$ & $\begin{array}{c}\text { Fresh } \\
\text { weight }\end{array}$ & $\begin{array}{c}\text { Ch }(\mathbf{a}) \\
(\mathbf{m g} / \mathbf{g})\end{array}$ & $\begin{array}{c}\text { Ch }(\mathbf{b}) \\
(\mathbf{m g} / \mathbf{g})\end{array}$ & $\begin{array}{c}\text { Carotenoids } \\
(\mathbf{m g} / \mathbf{g})\end{array}$ \\
\hline Control & & $3 \pm 0.22$ & $4.6 \pm 0.23$ & $0.45 \pm 0.05$ & $0.06 \pm 0.005$ & $0.31 \pm 0.05$ & $0.36 \pm 0.1$ & $0.228 \pm 0.50$ \\
FYM & $12 \mathrm{~g}$ & $6.5 \pm 0.50$ & $8.70 \pm 0.10$ & $0.99 \pm 0.03$ & $0.12 \pm 0.00$ & $0.38 \pm 0.03$ & $0.84 \pm 0.06$ & $0.33 \pm 0.30$ \\
Ulva & $12 \mathrm{~g}$ & $7.3 \pm 0.30$ & $9.30 \pm 0.53$ & $1.56 \pm 0.04$ & $0.25 \pm 0.03$ & $0.33 \pm 0.02$ & $0.875 \pm 0.06$ & $0.32 \pm 0.30$ \\
Jania & $12 \mathrm{~g}$ & $8.8 \pm 0.36$ & $9 \pm 0.61$ & $1.60 \pm 0.13$ & $0.22 \pm 0.03$ & $0.4 \pm 0.03$ & $1.15 \pm 0.07$ & $0.26 \pm 0.60$ \\
\hline
\end{tabular}

Table (7) Carbohydrate fractions (mg/g)of Trigonella foenum-graecum L treated with FYM and Ulva lactuca and Jania rubens after 30 days.

\begin{tabular}{lcccc}
\hline Treatment & Control & FYM & Ulva lactuca & Jania rubens \\
\hline Direct reducing value & $20.53 \pm 0.12$ & $24.87 \pm 0.20$ & $23.78 \pm 0.33$ & $23 \pm 0.050$ \\
Disaccharides & $30.71 \pm 0.12$ & $33.38 \pm 0.11$ & $31.10 \pm 0.50$ & $35.19 \pm 0.50$ \\
Total reducing sugar & $51.24 \pm 3.56$ & $58.25 \pm 0.94$ & $54.88 \pm 0.44$ & $58.19 \pm 0.30$ \\
Poly saccharides & $25.78 \pm 0.06$ & $24.04 \pm 0.03$ & $24.42 \pm 0.22$ & $24.65 \pm 0.42$ \\
Total carbohydrates & 77.02 & 82.29 & 79.30 & 82.84 \\
\hline
\end{tabular}

Table (8) Nitrogen fractions (mg/g) of Trigonella foenum-graecum L treated with FYM and Ulva lactuca and Jania rubens after 30 days.

\begin{tabular}{lcccc}
\hline & Different doses & FYM & Ulva lactuca & Jania rubens \\
& Control & $17.03 \pm 0.01$ & $17.03 \pm 0.010$ & $17.03 \pm 0.010$ \\
In soluble Protein & $12 \mathrm{~g}$ & $18.73 \pm 0.3$ & $19.01 \pm 0.050$ & $19.09 \pm 0.040$ \\
& Control & $11.08 \pm 0.03$ & $11.08 \pm 0.03$ & $11.08 \pm 0.030$ \\
Total soluble nitrogen & $12 \mathrm{~g}$ & $11.38 \pm 0.10$ & $31.27 \pm 0.10$ & $39.71 \pm 0.30$ \\
Total nitrogen & Control & $61.6 \pm 0.30$ & $61.6 \pm 0.30$ & $61.6 \pm 0.30$ \\
& $12 \mathrm{~g}$ & $71.6 \pm 0.30$ & $156 \pm 0.10$ & $180 \pm 0.08$ \\
\hline
\end{tabular}


Table (9) Free fatty acids composition (relative percentage) in Trigonella foenum-graecum seedling pretreated with FYM, Ulva lactuca, Jania rubens after 30 days.

\begin{tabular}{llccccc}
\hline Fatty acids & & C-Number & Control & FYM & Ulva lactuca & Jania rubens \\
\hline & Palmitic acid & $\mathrm{C}_{16: 0}$ & 10.30 & 12.40 & 7.055 & 6.50 \\
Saturated(SFA) & Stearic acid & $\mathrm{C}_{18: 0}$ & 7.00 & 9.70 & 4.30 & 3.11 \\
& Arachidic acid & $\mathrm{C}_{20: 0}$ & 6.70 & 7.60 & 1.73 & 1.26 \\
Sum \% & & - & 24.00 & 29.70 & 13.085 & 10.87 \\
Mon unsaturated(MUFA) & Oleic acid & $\mathrm{C}_{18: 1}$ & 23.00 & 22.00 & 28.20 & 28.73 \\
Sum\% & & - & 23.00 & 22.00 & 28.20 & 28.73 \\
Poly unsaturated(PUFA) & Linoleic acid & $\mathrm{C}_{18: 2}$ & 34.00 & 29.30 & 36.80 & 40.20 \\
Sum\% & Linolenic acid & $\mathrm{C}_{18: 3}$ & 19.00 & 19.00 & 22.00 & 20.20 \\
Un Sat/ Sat index & & - & 76.00 & 70.3 & 87 & 89.13 \\
\hline
\end{tabular}

\section{References}

[1] G.Povero, J.F.Mejia, T.D.Di, A.Piaggesi, P.Warrior, A systematic approach to discover and characterize natural plant biostimulants. Front. Plant Sci.vol.90,pp.74-35,2016.

[2] B.S.Hansra, Transfer of agricultural technology on irrigated agricultural. Fertilizer News.vol.38,pp.31-33,1993.

[3] V.K.Dhargalkar ,N.Pereira , Seaweeds :promising plants of the millennium .Sci.Cult.vol.71 ,pp.60-66,2005.

[4] A.K.Dwivedi, S.Singh, R.Ranjan, Suitable varieties of fenugreek for Jharkhand spices and medicinal and Aromatic plants in eastern region.vol.65,pp.95-101,2006.

[5] Z.Peiman, K.r B.Saikat, C. I.x.William, Fenugreek (Trigonella foenum-graecum L.): An important medicinal and aromatic Crop. In book: Active Ingredients from Aromatic and Medicinal Plants, Edition: 1st, Chapter: 12, Publisher: InTech.vol.66,pp.217-223,2017.

[6] J.Lee, D.Koo, B.Min, Reactive Oxygen Species, Aging, and Antioxidative Nutraceuticals. Comprehensive Rev Food Sci Food Safety.vol.3,pp.21-33,2004.

[7] S. Shabbeer, M.Sobolewski, R.K.Anchoori , S.Kachhap, M.Hidalgo, Fenugreek: a naturally occurring edible spice as an anticancer agent. Cancer Biol Ther.vol.8,pp.272-278,2009.

[8] S.R.Sharma, S.C.Bhandari, Effect of organic manure and mineral nutrients on symbiotic efficiency in cowpea. Indian Journal of Pulses Research.vol.15,pp.156-16,2002.

[9] B.G.Shiva Kumar, B.N.Mishra, C.S.Saraf, S.S.Balloli, Effect of soil and nutrient management on productivity of green gram wheat cropping sequence under limited water supply. Proceeding of international Conference on Managing Natural Resources for Sustainable Agricultural Production in the 21th Century, New Delhi, and.vol.3,pp.884$885,2000$.

[10] M.Pandey, J.Singh, M.Singh, Effect of integrated nutrient management on yield and nutrient uptake in cabbage and soil fertility. Annals of Plant and Soil Research.vol.9,pp.136-138,2007

[11] T.Abraham, O.V.S.Thenua, B.G.Shivakumar, Impact of levels of irrigation and fertility gradients on dry matter production, nutrient uptake and yield of chickpea (Cicer arietinum).Legum Research.vol.33,pp.1016,2010 .

[12] T.Arioli, S.W.Mattner, P.C.Winberg, Extracts in Australian agriculture: past, present and future.J.App.Phycol.vol.27,pp.207-201,2015.

[13] V.Krishnmurthy, Seaweeds wonder plants of the sea. Aquaculture foundation of India.vol.30,PP.89-120,2005.

[14] M.H.Seham, A.A.Amal, A.R.Neveen, B.M.Ibraheem, Role of marine macroalgae in plant protection and improvement for sustainable agriculture technology .Beni-Suef University Journal of Basic and Applied Sciences. Volume.vol.71,pp.104-110,2018.

[15] G.Thirumaran, M.Arumugam, R.Arum gam, P.Anantharaman, Effect of seaweed liquid fertilizer on growth and pigment concentration of Cyamopsis tetragonoloba (L.) Taub.Am.Euras.J.Agron.vol.2,pp.50-56,2009.

[16] H.Akash , S.Richa , Effect of different concentrations of commercial seaweed liquid extract of Ascophyllum nododum as plant biostimulant on growth, yield and biochemical constituents of onion (Allium cepa L.) J.of Pharma.and phytochem.vol.6,pp.658663,2017.

[17] A.EBIC, (European Bio stimulant Industry Council) http://www.biostimulants.eu/ website.vol.64.,pp.324-331,2012.

[18] J.S.Sangha, S.Kelloway, A.T.Critchley, Seaweeds (macroalgae) and their extracts as contributors of plant productivity and quality: The current status of our understanding. Sea Plants.vol.71,pp.125-159,2014.

[19] B.R.Rao, Narayana, gen. nov. From Burma and some synonyms (Hymenoptera: 
Mymaridae). Oriental Insects.vol.11,pp.8791,1976.

[20] H.Metzner , H.Rau, H.Senger, Under SuchungZur Synechronisier-barkeitein Zelner Pigmentamangel. Mutanten von Chlorella. Planta.vol.40,pp.65-186,1965.

[21] M.B.Allen, Exp. In Soil bacteriology Ist Wd. Burgess pupl. Cp.vol.35,pp.99-110,1953.

[22] H.Said, F.D.H. El.Shishiny, The effect of disc thickness on the respiration and the various nitrogen fractions of cut disc of radish root immersed in water and sugar solutions .Plant Physiol.Lanacasten.vol.19,pp.66-72,1944.

[23] O.H.Lowry,H.Rosebrough, A.L.Farr, R.J.Randall, Protein measurement by folinphenol reagent. J Biol. Chem.vol.193,pp.265275,1951.

[24] A.Said, M.I.Naguib, Sucrose determination as means of estimation of the draw, back tax Exported Halawa Teheinia .BULL. Fac.Cairo Univ.vol.39,pp.207-216,1964.

[25] N.Nelson, Photometric adaptation of Somgi method for the determination of glucose .J.Biol .Chem.vol.143,pp.275-281,1944.

[26] M.I.Naguib, Effect of seiven on the carbohydrates and nitrogen metabolism during the germination of cotton seeds. Ind.J.Exp.Biol.vol.2,pp.149 -152,1964.

[27] M.I.Naguib, Effect of colchicine on the nitrogen metabolism and the fate of phosphorus observed during the formation of fungal pelts of Cunninghamella sp.Arch .Microbiol.vol.47,pp.15-94,1963.

[28] M.Liu, T.Hong, "Simultaneous Determination of Phytohormones in Plant Extracts Using SPME and HPLC." Chromatographia.vol.66,pp.515-20,2007.

[29] G.V.Agoramoorthy,V.Chandrasekareu,M.Vem katesalu,J.Hsu,Antibacterial and antifungal activity of fatty acids methyl esters of blind your-eye mangrove from Indian Braz.J.Microbiol.vol.38,pp.739-742,2007.

[30] T.Piper, Soil and plant analysis " The University of Adelaide.vol.9,pp.51-66,1947.

[31] C.Perkin-Elmer, Analytical methods for atomic absorption Norwalk,Conn.vol.10,pp.77-90,1964):

[32] T. B.Marker, Multi-element analysis in plant materials analytical tools and biological questions. Environment Analysis.vol.7,pp.4956,1992 .

[33] L.A.Richard, Diagnosis and improvement of saline and alkaline soils .U.S. Department Agriculture Handbook 60 .U.S.Gov.Printing Office ,Washington,DC,vol.12,pp.88$105,1954$.

[34] M.Dejene, M.lemlem, Integrated Agronomic crop management to improve Tef productivity under terminal Drau glut water stress, In Tech open source.vol.9,pp.235-254,2012.
[35] W.Bayu, N.F.G.Rethman, P.S.Hammes, G.Alemu, Application of farm yield manure improved the chemical and physical properties of soil in a semi-arid area in Ethiopia. Biological Agriculture and Horticulture.vol.24,pp.293-300,2006.

[36] N.I.Khan, A.U.Malik, F.Umer, M.I.Bodla, Effect of tillage and farm yield manure or physical properties of soil. International Research Journal of plant science.vol.4,pp.7582,2010.

[37] X.D.Chenping, L.Leskovar, Effect of A.nodosum seaweed extracts on spinach growth, physiology and nutrition value under drought stress. SC.it ort.vol.183,pp.39-4,2015.

[38] R.Sekar, N.Thangaraju, R.Rengasamy ,Effect of seaweed liquid fertilizer from Ulva lactuca on Vigna unguiculata L.Phycos.vol.34,pp.4953,1995.

[39] A.USD, Agricultural research service. Nutrient Database for standard Refrence, Release.vol.56,pp.81-43,2000.

[40] E.Booth, The manufacture and properties of liquid seaweed extracts, Sixth international seaweed symposium, Madrid.. Journal of Agriculture and Social Sciences.vol.4,pp.165$169,1969$.

[41] M.Samoraj, S.Basladynska, K.Chojnacka, New micro nutrient fertilizer bio components based on seaweed biomass Pol. J.Environ.Stud .vol.24,pp.2213-2221,2015.

[42] N.J.L.Kumar, R.R.N.Kuma, 1. K.Pate, S.Viyol, R.Bhoi, Nutrient composition and calorific value of some seaweeds from bet dwarka, west coast of Gujarat, India. Our Nat .vol.7,pp.18-25,2009.

[43] S.J.Aldwoth, J.Van Staden, The effect of seaweed concentrate on seedling transplants .S.Afr. J .Bot.vol.53,pp.187 -18,1987.

[44] W.R.Nelson, J.Van Staden, The effect of seaweed concentrate on wheat colums.J.Plant Physiol .vol.115,pp.433-437,1986.

[45] N.Renuka Bai , L.N.R.Banu, J.W.Prakash, S.J.Goldi, Effects of Asparagopsis taxi formis extract on the growth and yield of phaseolus aureus. JBasic APPL BoiL.vol.1,pp.6-11,2007.

[46] N.A.Kumar, B.Vanlalzarzva, S.Sridhar , M.Baluswami , Effect of liquid seaweed fertilizer of Sargassum wightii Grev. on the growth and biochemical content of green gram (Vigna radiata (L.) R. Wilczek).Bioresource Technol .vol.104,pp.202-207,2012.

[47] G. Blunden, P.F.Morse, , I.Mathe, J.Hohmann, A.T.Critchleye, , S.Morrell, Betaine yields from marine algal species utilized in the preparation of seaweed extracts used in agriculture .Nat.Prod.Commun. vol.5,pp.581585,2010 .

[48] G.Kumar, P.Baweja, Biofertilizer: a tool for sustainable agriculture in chainging 
environment .In: Ansari MW, Kumar S. Kaula, B.C. Wattal, R.K. (eds).Introductin to challenges and strategies to improve crop productivity in changing environment.R.K. Enriched Public Pvt.L td, Dwark.vol.6,pp.8392.2018.

[49] O. M.Ismail, M.Kardoush, The impact of some nutrients substances on germination and growth seedling of Pistachio vera L. Aust. J. Basicand App. Sci.vol.5,pp.115-120,2011.

[50] M.Popescu , Agricultural uses of seaweeds extract.s .Current Trends in Natural Sciences.vol.1 ,pp.36-39,2012.

[51] W.Khan, U.P.Khan, S.Rayorath, M.N.Subramanian, P.Jithesh, D.M.Rayorath, A.T.Hodges, J.S.Critchley, J.Craigie, B.Norrie, (Seaweed extracts as biostimulants of plant growth and development. J. Plant Growth Regul.vol.28, pp. 386-39,2009.

[52] P. B., Wildgoose, G. Blunden, K.Jeewers, Seasonal variation in gibberellins activity of some species of fucaceae and laminariaceae.Bot.vol.21,pp.63-65,1993.

[53] K.Divya, M.N.Roja, S.B. Padal, Effect of seaweed liquid fertilizer of Sargassum wightii on germination, growth and productivity of brinjal. Int J Adv Res Sci Eng Technol. vol.2,pp.868-871,2015.

[54] S.R.Savasangari, S.Nagaraj, N.Vijayanand, Influence of seaweed liquid extracts on growth, biochemical and yield characteristics of CyamoPsis tetragonolabal (L) Taub. J phyto L .vol.10,pp.37-41,2011.

[55] w.A.Strik, G.D.Arthur, A. F.Lourens, O.Novok, M.Strand, N. Van Subhashini, A.Thangathirupathi, N. Lavanya, Changes in cytokinin and auxin concentrations in seaweed concentrates when stored at an elevated temperature, Int J Pharm Pharm Sci3.vol.9,pp.96-102,2014.

[56] B.Muthuraman, R.Ranganathan, Biochemical studies of some green algae of Kanyakumari coast. Seaweed.Res. Utiln.vol.26,pp.69-7, 2004.

[57] A.Levent Tuna, C.Kaya, M.Dikilitas, D.Higgs, The combined effect of gibberellic acid and salinity on some antioxidant enzyme activities, plant growth parameters and nutritional status in maize plants. Enviand Exp Botany.vol.26,pp.1-9,2008.

[58] G.Blunden, T.Jenkins, L.Y.Wan, Enhanced leaf chlorophyll levels in plants treated with seaweed extracts. J Appl Phycol.vol.8,pp.535$543,1997$.

[59] N. Atzmon, J.Van Staden, The effects of seaweed concentrate on the growth of Pinus pinea seedlings. New Forests.vo.18,pp.279$288,1994$.

[60] R.Vishnupriya , G.Flora, Effect of Ulva Lactuca Linn. and Padina tetrastromatica
Hauch concentrate on growth and yield of Lablab Purpureus L . Asian Journal of Biological and life Science.vol.6,pp.321328,2017.

[61] H.Opik, Changes in the fine structure of cotyledons of Phaseolus vulgaris L. during seed germination .J. Exp. Bot.vol.240,pp.1675$80,1966$.

[62] R.V.K.Dhargalka, T.G.Jagtap, A.G.Untawale, Biochemical constituents of seaweeds along the Maharastra coast. Indian J. Mar. Sci.vol.9,pp.297-299,1980.

[63] K.Miyamoto , S.Kamisaka, Growth and osmoregulation in Pisum sativum subhooks as affected by gibberellic acid and cotyledon excision,PhysiologiaPlantarum.vol.74,pp.669674,1988 .

[64] R. M. Devlin, Plant physiology, $3^{\text {rd }}$ ed .Affiliated East West Press, New Delhi.vol.32,pp.558-531,1983.

[65] X .Mancuso ,S.Azzarello ,E .Mungna ,S. Briand, Marine bioactive substances (IPA extract )improve ion fluxes and water stress tolerance in potted Vitis vinifera plants .Adva.Hortic .Sci .vol.20,pp.156 -161,2006.

[66] V.Erulan , G.Thirumaran , P.Soundarapandian , G.Ananthan, Studies on the effect of Sargassum polycystum extract on the growth and biochemical composition of Cajanus cajan (L.) Mill sp.Am. J.Agric andEnviron.Sci .vol.6,pp.392-399,2009.

[67] S.Sridhar, R.Rengasamy, Effect of seaweed liquid fertilizer on the growth, biochemical constituents and yield of Tagetes erecta, under filed trial. J. of phytology.vol.2,pp.61-68,2010.

[68] V.Subramaniyan, P.Malliga ,Effect of Cyanobith biofertilizer as basal and spray on Zea mays (Corn) cultivation. International Journal of Environmental Science.vol.2,pp. 212,2011 .

[69] S.M.Abbas, The influence of bio stimulants on the growth and the biochemical composition of Vicia faba cv. Giza 3 beans .Rom. Biotechnol.Lett.vol.18,pp.8061-8068,2013.

[70] M.Anantharaj, V.Venkatesalu, studies on the effect of seaweed extracts of Dolichos biflorus. Weaweed Res. Utiln.vol.24,pp.129- 137, 2009.

[71] M.M.El-Sheekh , A.El-Saied,Effect of crude seaweed extracts on seed germination, seedling growth and some metabolic processes of Vicia faba L. Cytobios.vol.101,pp.23-35,2000.

[72] K.Lingakumar, D.Balasubramanian, S.K.G.Sundar, R.Jeyaprakash, M.Jeyakumar, Effect of Ulva lactuca crude extract on growth and biochemical characteristics in Cyamopsis tetragonoloba L. and Phaseolus mungo. Seaweed Res. Utiln.vol.28,pp.75-80,2006.

[73] A.J.Salle, Laboratory Manual on Fundamental Principles of Bacteriology. McGraw-Hill Book 
Company, New York, USA.vol.5,pp.6688,1973 .

[74] A.Fatiha, plant liquid metabolism. DOI:10.5772/intechopen.vol.8,pp.13-55,2019.

[75] M. M. El-Sheek, H.H. Omar, effect of high salt stress or growth and fatty acids content of the unicellular green alga. Chlorella vulgaris. A,ZJ.Microb.vol.7,pp.181-191,2002.
[76] M.M.Shehata, S.A.El-Khawas, Effect of two biofertilizers on growth parameters, yield characters, nitrogenous components, nucleic acids content, minerals, oil content, protein profiles and DNA banding pattern of Sunflower yield. Pakistan Journal of Biological Sciences.vol.6, pp.1257-1268,2003. 